\title{
Analisis Implementasi Pembelajaran di Sekolah Dasar pada Pengembangan Model Advance Organizer berbasis Pendekatan Open Ended untuk Meningkatkan Penalaran Siswa
}

\author{
Joko Sulianto ${ }^{1^{*}}$, Sunardi ${ }^{2}$, Sri Anitah ${ }^{3}$, Gunarhadi ${ }^{4}$ \\ ${ }^{1}$ Program Doktor Ilmu Pendidikan, Universitas Sebelas Maret Surakarta \\ 2,3,4 Fakultas Keguruan dan Ilmu Pendidikan, Universitas Sebelas Maret Surakarta
}

\section{A R T I C LEINFO}

Article history:

Received 18 August 2019 19 September 2019

Accepted 25 October 2019

November 2019

Kata Kunci:

Implementasi

Pembelajaran

Pengembangan Model, dan

Penalaran Siswa

Keywords:

Implementation of Learning

Model Development, and

Reasoning Students
Received in revised form

Available online 30

\begin{abstract}
A B S T R A K
Tujuan dari penelitian ini adalah untuk mendekripsikan pelaksanaan pembelajaran di sekolah dasar. Fokus penelitian adalah implementasi pembelajaran kurikulum 2013, mengimplementasikan model pembelajaran yang diperkenalkan pada kurikulum 2013. Penelitian ini menggunakan pendekatan penelitian dan pengembangan yang difokuskan pada tahap studi pendahuluan dengan menggunakan pendekatan deskriptif kualitatif. Penelitian ini dilaksanakan di kota semarang dengan melibatkan 45 responden dari satuan pendidikan dasar. Data diperoleh dengan membagikan angket kepada responden. Teknik analisis data yang digunakan adalah teknik analisis deskriptif aktivitas dalam analisis data yaitu data reduction, data display, dan conclusion, drawing/verification. Data hasil penelitian menunjukkan bahwa satuan pendidikan dasar telah mengimplementasikan pembelajaran pada kurikulum 2013, meskipun masih perlu ditingkatkan kualitasnya. Pemahaman guru-guru dalam mengimplementasikan model pembelajaran yang diperkenalkan dalam kurikulum 2013 juga baik, pelaksanaan pembelajaran dilaksanakan dengan berpusat pada
\end{abstract} peserta didik, (2) Implementasi K13 berjalan dengan baik, meskipun pada awalnya guru harus menyesuaikan dengan perubahan pola mengajar dan perangkat pembelajaran, dengan adanya diklat dan pelatihan-pelatihan sangat membantu, (3) Model yang diperkenalkan pada kurikulum 2013 telah membantu dalam peningkatan kemampuan bernalar siswa, akan tetapi perlu ditingkatkan kualitas pembelajarannya, (4) pembelajaran harus berpusat pada siswa, guru sebagai fasilitator, bahwa pembelajaran harus memberikan kesempatan kepada siswa untuk mencari tahu penyelesaian sebuah persoalan atau berinteraksi dengan lingkungan sosialnya, (5) model pembelajaran yang mudah diimplementasikan, model yang memberikan kesempatan kepada siswa mengemukakan ide atau gagasan, dan memfasilitasi siswa berikir kritis, model pembelajaran yang memberikan kesempatan kepada siswa untuk bernalar, aktif dalam pembelajaran menyampaikan ide dan argumentasi atau memberikan alasan-alasan.

\section{A B S T R A C T}

The purpose of this study was to describe the implementation of learning in elementary schools. The focus of research was the learning implementation in kurikulum 2013, implementing learning models introduced in kurikulum 2013. This study uses a research and development approach that is focused on the preliminary study stage by using a qualitative descriptive approach. This research was conducted in Semarang by involving 45 respondents from the basic education unit. Data obtained by distributing questionnaires to respondents. The data analysis technique used is the activity analysis descriptive technique in data analysis, namely data reduction, data display, and conclusion, drawing/verification. Data The results of the study indicate that the basic education unit has implemented learning in the 2013 curriculum, although it still needs to be improved in quality. Teachers' understanding in implementing the learning model introduced in the 2013 curriculum is also good, the implementation of learning is carried out centered on students, (2) The implementation of K13 runs well, although initially teachers must adjust to changes in teaching patterns and learning tools, with education and training are very helpful, (3) The model introduced in the 2013 curriculum has helped in increasing students' reasoning abilities, but needs to improve the quality of learning, (4)

\footnotetext{
${ }^{1}$ Corresponding author.

E-mail addresses: $\underline{\text { sulianto.jo@student.uns.ac.id, email (Joko Sulianto) }}$
} 
learning must be student-centered, the teacher as a facilitator, that learning must provide opportunities for students to find out the solution of a problem or interact with their social environment, (5) learning models that are easy to implement, models that provide opportunities for students to express ideas or ideas, and facilitate students' critical thinking, learning models that provide health observations to students to reason, be active in learning to convey ideas and arguments or provide reasons.

Copyright (C) Universitas Pendidikan Ganesha. All rights reserved.

\section{Pendahuluan}

Pendidikan memegang peranan sangat penting dan strategis dalam membangun masyarakat berpengetahuan yang memiliki keterampilan: (1) melek teknologi dan media, (2) melakukan komunikasi efektif, (3) berpikir kritis, (4) memecahkan masalah, dan (5) berkolaborasi. Merespon perkembangan era masyarakat informasional dan komunikasional yang ditandai oleh kehadiran media baru, pemerintah dalam pembangunan sektor pendidikan mengeluarkan kebijakan yang berisi pemanfaatan ICT dalam pembelajaran, penerapan kurikulum 2013 juga mendorong proses pembelajaran berbasis ICT. Kehadiran ICT dalam dunia pendidikan bisa membawa dampak positif apabila teknologi dimanfaatkan untuk meningkatkan kualitas pembelajaran tetapi bisa menjadi permasalahan baru apabila lembaga pendidikan tidak siap.

Perubahan karakter masyarakat secara fundamental berimplikasi terhadap karakteristik guru. Perubahan karakteristik masyarakat diikuti tranformasi kultur guru dalam proses pembelajaran. Kemampuan guru sebagai fasilitator harus diperkuat, guru mengarahkan pembelajaran lebih banyak pada diskusi, memecahkan masalah, dan berpikir kritis. Dengan demikian kemampuan siswa dalam penalaran sangat mempengaruhi keterampilan pemecahan masalah dan berpikir kritis karena penalaran merupakan cara berfikir dengan membuat kaitan antara pengetahuan atau informasi yang telah dimiliki siswa dihadapkan dengan informasi baru atau situasi baru untuk kemudian membuat agumentasi argumentasi maupun kesimpulan. Paradigma ini mengubah cara pandang guru dari teacher center menjadi student center. Guru abad 21 harus kreatif dan inovatif dalam mengembangkan metode belajar atau mencari pemecahan masalah belajar.

Ada beberapa kecakapan yang harus dimiliki oleh generasi abad 21 mencakup nilai dan perilaku. Keterampilan dan kecakapan abad 21 mencakup tiga kategori utama, yaitu: (1) keterampilan belajar dan inovasi meliputi berpikir kritis dan pemecahan masalah dalam komunikasi dan kreativitas kolaboratif dan inovatif, (2) keahlian literasi digital meliputi literasi media baru dan literasi ICT, (3) kecakapan hidup dan karier meliputi memiliki kemampuan inisiatif yang fleksibel dan inisiatif adaptif, dan kecakapan diri secara sosial dalam interaksi antar budaya, kecakapan kepemimpinan produktif dan akuntebel, serta bertanggungjawab. Dalam abad 21 menuntut karakteristik siswa yang memiliki keterampilan belajar dan inovasi, yaitu yang berkaitan dengan kemampuan berpikir kritis.

Kemampuan berpikir kritis menuntut kebebasan berpikir dalam suatu proses pembelajaran, kebebasan berfikir dalam suatu proses pembelajaran bisa didapat dengan melakukan pengembangan model advance organizer berbasis pendekatan open ended. Model advance organizer memberikan kesempatan luas peserta didik menyajikan kebebasan berfikir melalui presentasi dan diskusi antar siswa dan guru dan didukung karakteristik pendekatan open ended yaitu problem yang diformulasikan memiliki multijawaban yang benar disebut problem tak lengkap disebut juga problem open ended atau problem terbuka (Shimada, 2005: 4). Pendekatan pembelajaran yang berpusat pada siswa (student center) menjadi keharusan, siswa dipandang sebagai subjek aktif yang memiliki daya seleksi dan daya interprestasi, serta daya kreasi tinggi terhadap topik apa yang diangkat dalam suatu proses pembelajaran. Pendekatan ini bukan berprinsip benar atau salah, tetapi prinsipnya bagaimana mengembangkan kemampuan bernalar dan beragumentasi siswa. Untuk menjawab pendekatan pembelajaran yang berpusat pada siswa, perlu dilakukan pengembangan model pembelajaran yang berpusat pada siswa. Model advance organizer berbasis pendekatan open ended memberikan banyak kesempatan kepada siswa untuk terlibat aktif dan banyak berbuat di dalam proses pembelajaran.

Pengembangan model pembelajaran advance organizer dengan pendekatan open ended berorientasi pada prinsip mengembangkan kemampuan bernalar dan beragumentasi siswa. Hal ini sejalan dengan penelitian yang dilakukan pamungkas, 2016 yang menyatakan bahwa pencapaian serta peningkatan kemampuan berpikir kritis dan kreatif matematis siswa dengan menggunakan model Advance Organizer lebih baik dibandingkan siswa yang mendapatkan pembelajaran biasa. Untuk mendapatkan kemampuan berpikir kritis perlu didukung kemampuan penalaran yang baik seperti yang 
dikemukakan Parjayanti, 2013 dari hasil penelitiannya menyatakan bahwa pembelajaran Inkuiri dan menggunakan pembelajaran Advance Organizer efektif untuk penalaran matematis peserta didik, dan pembelajaran Advance Organizer lebih efektif untuk penalaran matematis peserta didik daripada pembelajaran Inkuiri.

(Kemendikbud, 2014, 2016) menyatakan pembelajaran merupakan proses interaksi antar peserta didik dan antara peserta didik dengan pendidik dan sumber belajar pada suatu lingkungan belajar. Proses pembelajaran diselenggarakan secara interaktif, menyenangkan, menantang, inspiratif, memotivasi peserta didik untuk berpartisipasi aktif, serta memberikan ruang yang cukup bagi prakarsa, kreativitas, dan kemandirian sesuai dengan bakat, minat, kemampuan, dan perkembangan fisik serta psikologis peserta didik.

Proses pembelajaran yang diselenggarakan secara interaktif, menyenangkan, menantang, inspiratif, memotivasi peserta didik untuk berpartisipasi aktif ini menjadikan penalaran sangat penting bagi peserta didik untuk meningkatkan kreativitas, kemandirian, mengembangkan kemampuan memecahkan masalah dan berpikir kritis. Penalaran merupakan suatu kegiatan, suatu proses atau aktivitas berpikir untuk menarik kesimpulan atau membuat suatu pernyataan baru yang benar berdasar pada beberapa pernyataan yang kebenarannya telah dibuktikan atau diasumsikan (Shadiq, 2004: 2). Penalaran merupakan kegiatan berpikir dalam mengembangkan argumentasi untuk meyakinkan orang lain atas pernyataan tertentu atau dalam menyelesaikan masalah atau untuk mengintegrasikan ide dalam pemecahan masalah (Brodie, 2010: 14). Penalaran adalah proses berpikir yang logis dan sistematis atas fakta-kata empiris yang dapat diobservasi untuk memperoleh simpulan berupa pengetahuan (Kemendikbud, 2015: 140). Penalaran adalah cara menarik kesimpulan dan mengevaluasi suatu kesimpulan sahih atau tidak sahih, suatu proses berpikir yang menghubungkan fakta-fakta yang diketahui menuju pada suatu kesimpulan (Suharnan, 2005: 157).

Schunk (2012: 432) menyatakan bahwa penalaran mengacu pada proses mental yang tercakup dalam pembuatan dan pengevaluasian argumen logis. Fisher (2009: 15) penalaran merupakan argumentasi-argumetasi untuk mendukung suatu pandangan dengan menyajikan sebuah alasan-alasan. Shadiq (2004: 2) menyatakan penalaran merupakan suatu kegiatan, suatu proses atau suatu aktifitas berpikir untuk menarik kesimpulan atau membuat suatu pernyataan baru yang benar berdasarkan pada beberapa pernyataan yang kebenarannya telah dibuktikan atau diasumsikan sebelumnya. dalam penelitian ini penalaran adalah kegiatan menghubungkan fakta fakta atau proses berpikir dalam mengembangkan argumentasi untuk menarik kesimpulan atau memberikan jawaban dalam pemecahan masalah.

Penelitian yang dilakukan oleh Kusumawardani (Kusumawardani, 2018) menunjukkan bahwa kemampuan penalaran dapat meningkatkan kemampuan literasi matematika siswa dengan cara memberikan tugas-tugas, sehingga siswa menggunakan kemampuan penalaran untuk memecahkan tugastugas tersebut untuk kemudian menyebabkan kemampuan literasi matematika meningkat. Hal ini menunjukkan bahwa kemampuan penalaran siswa menjadi sangat penting untuk ditingkatkan, dalam penelitian ini peningkatan penalaran siswa dilakukan dengan pengembangan model advance organizer berbasis pendekatan open ended karena dengan pengembangan model ini memberikan kesempatan kepada siswa untuk mengeksplorasi ragam jawaban sehingga berpotensi meningkatkan penalaran siswa.Jadi dalam penyelesaian masalah diperlukan proses bernalar, atau dalam mengambil sebuah keputusan atau kesimpulan atau dalam memberikan argumentasi argumentasi diperlukan kemampuan penalaran yang memadai, penalaran merupakan aktivitas berpikir dalam mengaitkan pengetahuan yang dimiliki dengan situasi permasalahan baru sehingga dengan terkaitnya fakta fakta pengetahuan yang dimiliki bisa digunakan untuk membuat argumentasi atau membuat kesimpulan. Baig \& Halai (2006: 27) menyatakan bahwa ada dua faktor penting yang memungkinkan siswa untuk belajar aturan-aturan dengan penalaran: Guru bertanya dan memberikan kesempatan bagi siswa untuk menjelaskan pemikiran; dan memberikan kesempatan bagi siswa untuk terlibat dengan benda benda konkret dan semi konkret.

Untuk mecapai keterampilan yang diharapkan pada abad 21 yaitu pembelajaran inovatif pada kemampuan berpikir kritis dan pemecahan masalah menjadikan penalaran matematika sangat penting untuk membantu siswa dalam mengemukakan argumentasi dan membuat kesimpulan maka perlu dikembangkan model pembelajaran yang mampu mengembangkan kemampuan tersebut. Dalam penelitian ini akan dikembangkan model advance organizer berbasis pendekatan open ended untuk meningkatkan kemampuan penalaran siswa di sekolah dasar. Dengan dikembangkannya model advance organizer berbasis pendekatan open ended diharapkan dapat meningkatkan kemampuan penalaran siswa karena pada model yang dikembangkan ini berorientasi pada bagaimana pengetahuan dikelola, bagaimana pikiran bekerja dalam memproses informasi baru, menberikan kesempatan kepada siswa untuk menginvestigasi berbagai strategi dan cara yang diyakininya sesuai dengan kemampuan 
mengelaborasi permasalahan. Dengan demikian berpotensi untuk meningkatkan kemampuan penalaran siswa di sekolah dasar.

\section{Metode}

Penelitian ini dilaksanakan menggunakan jenis penelitian dan pengembangan. Penelitian dan pengembangan adalah suatu proses atau langkah langkah untuk mengembangkan suatu produk baru atau menyempurnakan produk yang telah ada, yang dapat dipertanggungjawabkan (Sukmadinata, 2012: 164). Penelitian pengembangan adalah suatu proses yang dipakai untuk mengembangkan dan memvalidasi produk pendidikan (Setyosari, 2012: 214). Menurut Gall, Gall \& Borg, (2007: 589) penelitian dan pengembangan berasal dari industri yang digunakan sebagai prosedur untuk merancang dan mengembangkan suatu produk baru yang berkualitas. Produk yang dikembangkan dalam pendidikan dapat berupa perangkat keras seperti alat bantu pembelajaran, buku, modul atau paket belajar atau perangkat lunak seperti program-program pendidikan dan pembelajaran, model model pendidikan, kurikulum, implementasi, evaluasi dan instrumen pengukuran. Sukmadinata, (2012: 171).

Dalam pelaksanaan penelitian dan pengembangan Sukmadinata, (2012: 167) menyatakan bahwa metode yang digunakan yaitu metode deskriptif, evaluatif, dan eksperimental. Pada tahap pendahuluan tentang analisis implementasi pembelajaran di sekolah dasar metode yang digunakan adalah metode deskriptif kualitatif.

Metode kualitatif digunakan untuk penelitian dan pengumpulan data, pengukuran kebutuhan, studi literatur dan pertimbangan-pertimbangan dari segi nilai. Penelitian kualitatif pada umumnya bersifat deskriptif dan menggunakan analisis dengan pendekatan induktif untuk menemukan konsep, teori atau bahkan filosofi yang berbasis pada data melalui proses reduksi. Penelitian kualitatif pada umumnya bersifat dekriptif, peneliti sebagai instrumen kunci disamping instrumen pendukung pedoman wawancara, panduan observasi, angket atau alat-alat rekam video dan audio.

Tahap pendahuluan ini bertujuan (1) untuk mengkaji tentang standar kompetensi lulusan, standar isi dan standar proses pembelajaran untuk pendidikan dasar dan menengah. Standar kompetensi lulusan memberikan kerangka konseptual tentang sasaran pembelajaran yang harus dicapai, standar isi memberikan kerangka konseptual tentang kegiatan belajar dan pembelajaran yang diturunkan dari tingkat kompetensi dan ruang lingkup materi, standar proses pembelajaran merupakan kriteria mengenai pelaksanaan pembelajaran pada satuan pendidikan untuk mencapai standar kompetensi lulusan. sasaran pembelajaran mencakup ranah sikap, pengetahuan dan keterampilan yang dielaborasi untuk setiap satuan pendidikan. Mengkaji bagaimanakah proses pembelajaran yang berlangsung pada satuan pendidikan dasar untuk mencapai standar kompetensi lulusan, mengkaji perencanaan pembelajaran, pelaksanaan pembelajaran dan penilaian pembelajaran. Mengkaji kemampuan bernalar atau penalaran siswa yang merupakan salah satu gradasi dari sasaran pembelajaran. (2) mengkaji tentang implementasi pembelajaran pada penerapan kurikulum 2013. Pada kegiatan mengkaji implementasi pembelajaran peneliti membagikan membagikan angket kepada 45 guru dan kepala sekolah di kota semarang.

Angket yang dibagikan kepada guru dan kepala sekolah untuk mendapatkan gambaran tentang bagimanakah pelaksanaan pembelajaran di sekolah dengan menerapkan model pembelajaran yang berpusat pada siswa, menanyakan tentang pentingnya kemampuan penalaran, mendeskripsikan bagaimanakah pembelajaran seharusnya dilaksanakan. Dam memberikan rekomendasi tentang pengembangan model yang akan dilakukan.

\section{Hasil dan Pembahasan}

Hasil penelitian yang ditampilkan pada artikel ini adalah hasil penelitian tahap pendahuluan dengan pendekatan deskriptif kualitatif mengenai implementasi pembelajaran di sekolah dasar. Berdasarkan hasil penelitian yang diperoleh dari angket yang dibagikan kepada 45 responden guru memberikan gambaran sebagai berikut: tentang pelaksanakan kurikulum 2013 semua sekolah telah mengimplementasikan kurikulm 2013 dan pemahaman konsep tentang implementasi kurikulum semua responden sudah baik. Salah satu jawaban responden tentang bagaimanakah implementasi pembelajaran pada kurikulum 2013 sebagai berikut: responden ke-R10 menjawab konsep implementasi kurikulum 2013 adalah siswa dalam proses pembelajaran diharapkan mampu menyelesaikan konsep dasar tidak hanya sekedar bisa mengerjakan soal dengan benar saja tetapi harus mampu menalar sehingga benarbenar paham, berikut hasil angket yang disajikan secara acak tentang pemahaman implementasi kurikulum 2013. Melihat respon dan jawaban guru maka dalam pelaksanaan kurikulum 2013 guru telah memiliki pengetahuan yang cukup mengenai pembelajaran yang sesuai atau diharapkan dalam kurikum 2013. 
Tabel 1. Pemahaman guru terhadap implemenasi pembelajaran kurikulum 2013

\begin{tabular}{|c|c|c|c|c|}
\hline Pertanyaan & R7 & R8 & R9 & R14 \\
\hline $\begin{array}{l}\text { Bagaimanakah } \\
\text { konsep } \\
\text { implementasi } \\
\text { pembelajaran } \\
\text { dengan penerapan } \\
\text { kurikulum 2013? }\end{array}$ & $\begin{array}{l}\text { proses } \\
\text { pembelajaran } \\
\text { mendorong } \\
\text { siswa menjadi } \\
\text { aktif dalam KBM. } \\
\text { Menggunakan } \\
\text { model } \\
\text { pembelajaran } \\
\text { aktif yang } \\
\text { menuntut siswa } \\
\text { aktif sehingga } \\
\text { memperoleh } \\
\text { pengalaman } \\
\text { belajar yang } \\
\text { baru. }\end{array}$ & $\begin{array}{l}\text { Pembelajaran } \\
\text { dengan penerapan } \\
\text { kurikulum } 2013 \\
\text { lebih } \\
\text { menyenangkan, } \\
\text { siswa diajak aktif } \\
\text { dalam } \\
\text { pembelajaran, tidak } \\
\text { hanya pasif } \\
\text { menerima } \\
\text { informasi dari guru. }\end{array}$ & $\begin{array}{l}\text { Konsep } \\
\text { Implementasi } \\
\text { pembelajaran K } \\
13 \text { menggunakan } \\
\text { pendekatan } \\
\text { scientifik } \\
\text { learning, siswa } \\
\text { menjadi lebih } \\
\text { aktif dan } \\
\text { utamanya guru } \\
\text { sebagai motivator } \\
\text { dan fasilitator }\end{array}$ & $\begin{array}{l}\text { 1. Proses } \\
\text { Pembelajaran } \\
\text { pada satuan } \\
\text { pendidikan } \\
\text { diselenggarakan } \\
\text { secara interaktif, } \\
\text { inspiratif, } \\
\text { menyenangkan, } \\
\text { peserta didik } \\
\text { untuk } \\
\text { berpartisipasi } \\
\text { aktif, }\end{array}$ \\
\hline
\end{tabular}

Dari Tabel 1. menunjukkan bahwa di sekolah telah menerapkan kurikulum 2013 dengan baik, pemahaman guru-guru dalam mengimplementasikan model pembelajaran yang diperkenalkan dalam kurikulum 2013 juga baik. Dari respon di atas menunjukkan bahwa pelaksanaan pembelajaran dilaksanakan dengan berpusat pada peserta didik.

Terkait dengan pelaksanaan pembelajaran kemudian dipertanyakan kepada responden bagaimanakah implementasi pembelajaran yang berlangsung saat ini, respon guru seperti pada tabel berikut:

Tabel 2. Gambaran Implementasi pembelajaran yang berlangsung di sekolah

\begin{tabular}{|c|c|c|c|c|}
\hline Pertanyaan & R2 & R4 & R7 & R8 \\
\hline $\begin{array}{l}\text { Bagaimanakah } \\
\text { implementasi } \\
\text { pembelajaran } \\
\text { pada kurikulum } \\
2013 \text { yang } \\
\text { sedang } \\
\text { berlangsung? }\end{array}$ & $\begin{array}{l}\text { Pembelajaran } \\
\text { Tematik Saintifik. } \\
\text { Penilaian otentik } \\
\text { pada proses dan } \\
\text { hasil belajar. } \\
\text { Penerapan model } \\
\text { model } \\
\text { pembelajaran } \\
\text { untuk mendukung } \\
\text { KBM. }\end{array}$ & $\begin{array}{l}\text { Sudah } \\
\text { berjalan } \\
\text { akan tetapi } \\
\text { belum } \\
\text { maksimal }\end{array}$ & $\begin{array}{lr}\text { Implementasi } & \text { K13 } \\
\text { berjalan dengan baik, } \\
\text { meskipun pada awalnya } \\
\text { guru harus } \\
\text { menyesuaikan dengan } \\
\text { perubahan pola } \\
\text { mengajar dan perangkat } \\
\text { pembelajaran. Lambat } \\
\text { laun juga bisa diikuti } \\
\text { dengan baik dengan } \\
\text { adanya diklat dan } \\
\text { pelatihan-pelatihan yang } \\
\text { mendukung. }\end{array}$ & $\begin{array}{l}\text { Perlu } \\
\text { pengembangan, } \\
\text { masih minim } \\
\text { materi, guru dan } \\
\text { siswa masih perlu } \\
\text { mencari referensi } \\
\text { dari sumber } \\
\text { belajar lain. }\end{array}$ \\
\hline
\end{tabular}

Tabel 2 menunjukkan bahwa terkait dengan bagaimana pelaksanaan pembelajaran yang saat ini sedang berlangsung beberapa responden memberikan tanggapan yang beragam, misalnya R2 menyatakan Pembelajaran Tematik Saintifik, Penilaian otentik pada proses dan hasil belajar, Penerapan model model pembelajaran untuk mendukung KBM. Dan respon dari responden yang lain bisa dilihat pada tabel di atas. Terkait dengan implementasi model pembelajaran yang diperkenalkan pada kurikulum 2013 yaitu model discovery learning, problem solving, dan project base learning responden sepakat menjawab bahwa model tersebut telah membantu menyajikan pembelajaran yang berpusat pada siswa, memberikesempatan siswa berpikir dan menyampaikan pendapat, akan tetapi dalam pelaksanaannya belum maksimal, salah satu jawaban responden bahwa model yang diperkenalkan sangat membantu, akan tetapi untuk meningkatkan kualitas pembelajaran perlu dilakukan pengembangan pembelajaran baik model, sumber belajar maupun media.

Berdasarkan data yang diperoleh dari angket terkait dengan pertanyaan Apakah model pembelajaran yang diperkenalkan pada kurikulum 2013 membantu dalam meningkatkan aspek penalaran siswa. Berikut datanya dapat dilihat pada Tabel 3. 
Tabel 3. Data hasil penelitian implikasi model terhadap penalaran siswa

\begin{tabular}{lllllr}
\hline \multicolumn{1}{c}{ Pertanyaan } & \multicolumn{2}{c}{ R2 } & \multicolumn{2}{c}{ R3 } & \multicolumn{2}{c}{ R11 } \\
\hline Apakah model & Membantu, & Ya, dengan & Iya, karena model & Model & yang \\
pembelajaran & karena sintak & model & pembelajaran & diperkenalkan & pada \\
yang & yang terdapat & pembelajaran & yang digunakan & kurikulum 2013 telah \\
diperkenalkan & dalam model & tersebut dapat & mengarahkan & membantu & dalam \\
pada kurikulum & pembelajaran & membantu dalam & siswa untuk peningkatan kemampuan \\
2013 & tersebut & menumbuhkan & menemukan & bernalar siswa, akan \\
membantu & melatih siswa & penalaran siswa & jawabannya & tetapi perlu ditingkatkan \\
dalam & untuk materi & sendiri melalui & kualitas pembelajarannya \\
meningkatkan & menyelesaikan & pembelajaran & pengalaman & \\
aspek penalaran & masalah & & belajar sehingga & \\
siswa? & sehingga & & penalaran dalam & \\
& otomatis & & berfikir & \\
& meningkatkan & & meningkat. & \\
& penalaran & & & \\
\end{tabular}

Dari Tabel 3 dapat dilihat bahwa model pembelajaran yang diperkenalkan sudah dapat meningkatkan penalaran siswa akan tetapi perlu ditingkatkan kualitasnya.

Data hasil penelitian berikutnya adalah tentang bagaimana pembelajaran yang seharusnya dilakukan data dapat dilihat pada Tabel 4 berikut:

Tabel 4 Data penelitian tentang kegiatan pembelajaran yang diharapkan

\begin{tabular}{lllll}
\hline \multicolumn{1}{c}{ Pertanyaan } & \multicolumn{1}{c}{ R2 } & \multicolumn{1}{c}{ R4 } & \multicolumn{1}{c}{ R8 } \\
\hline Bagaimanakah & Pembelajaran & Yang dapat & Pembelajaran & Memfasilitasi \\
Seharusnya & harus berpusat & meningkatkan & berorientasi/berpusat & siswa untuk \\
pembelajaran & pada siswa, penalaran siswa & $\begin{array}{l}\text { pada siswa guru sebagai berkarya, lebih } \\
\text { fasilitator dan evaluator }\end{array}$ banyak \\
dilaksanakan? & guru sebagai & & terhadap gagasan atau memperoleh \\
& fasilitator & & pengalaman & ilmu \\
& pemecahan & belajar/temuan siswa. & pengetahuan, \\
& masalah. Dan & & membekas \\
& siswa diberi & & dalam ingatan, \\
& kesempatan & & dan \\
& untuk mencari & & menenangkan \\
& tahu sendiri & & & \\
\hline
\end{tabular}

Dari Tabel 4 di atas menunjukkan bahwa bagaimanakah pembelajaran seharusnya dilaksanakan, salah satu responden memberikan tanggapan bahwa pembelajaran harus berpusat pada siswa, guru sebagai fasilitator, bahwa pembelajaran harus memberikan kesempatan kepada siswa untuk mencari tahu penyelesaian sebuah persoalan atau berinteraksi dengan lingkungan sosialnya.

Setelah beberapa pertanyaan terkait dengan implementasi pembelajaran pada kurikulum 2013. Pertanyaan berikutnya adalah tentang bagimanakah model pembelajaran yang responden harapkan, datanya dapat dilihat pada Tabel 5 berikut:

Tabel 5. Model pembelajaran yang diharapkan

\begin{tabular}{|c|c|c|c|c|}
\hline Pertanyaan & R1 & R2 & R7 & R8 \\
\hline Model & Yang dapat & Model & Model pembelajaran yang & Model \\
\hline $\begin{array}{l}\text { yang } \\
\text { bagaimanakah } \\
\text { yang }\end{array}$ & $\begin{array}{l}\text { alterapkan ke } \\
\text { siswa secara baik, } \\
\text { mudah dalam } \\
\text { implememtasinya }\end{array}$ & $\begin{array}{l}\text { pempeiajaran } \\
\text { yang benar } \\
\text { benar memberi } \\
\text { kesempatan }\end{array}$ & $\begin{array}{l}\text { mampu meningkatkan } \\
\text { kemampuan nalar siswa, } \\
\text { berani } \\
\text { berpendapatmenyenangkan }\end{array}$ & $\begin{array}{l}\text { pembelajaran } \\
\text { yang simple, } \\
\text { menyenangkan, } \\
\text { membangun }\end{array}$ \\
\hline $\begin{array}{l}\text { Bapak/Ibu } \\
\text { harapkan? }\end{array}$ & $\begin{array}{l}\text { namun } \\
\text { mempunyai }\end{array}$ & $\begin{array}{l}\text { kepada siswa } \\
\text { untuk }\end{array}$ & $\begin{array}{l}\text { dan mudah direalisasikan } \\
\text { bagi guru. }\end{array}$ & $\begin{array}{l}\text { kebiasaan siswa } \\
\text { untuk berpikir }\end{array}$ \\
\hline
\end{tabular}




\begin{tabular}{llll}
\hline dampak yang & mengemukakan & dan menalar, \\
realistis bagi & ide, gagasan dan & malam \\
kebutuhan siswa & pendapat yang & daktif \\
& melatih siswa & pembelajaran. \\
& berpikir kritis \\
& dan logis.
\end{tabular}

Dari data di atas menunjukan bahwa pengembangan model yang diharapkan guru adalah model pembelajaran yang mudah dalam implementasinya, model yang memberikan kesempatan kepada siswa mengemukakan ide atau gagasan dan memfasilitasi siswa berikir kritis, model pembelajaran yang memberikan kesempatan kepada siswa untuk bernalar, aktif dalam pembelajaran menyampaikan ide dan argumentasi atau memberikan alasan-alasan.

Dari hasil penelitian di atas dapat digunakan sebagai dasar dalam pengembangan model pembelajaran baru yang dapat meningkatkan kemampuan penalaran siswa. Pengembangan model pembelajaran advance organizer berbasis pendekatan open ended. Prinsip pembelajaran yang digunakan dalam Kurikulum 2013 yang mendukung pengembangan model advance organizer berbasis pendekatan open ended sebagai berikut: (1) dari peserta didik diberi tahu menuju peserta didik mencari tahu; (2) dari guru sebagai satu-satunya sumber belajar menjadi belajar berbasis aneka sumber belajar; (3) dari pendekatan tekstual menuju proses sebagai penguatan penggunaan pendekatan ilmiah; (4) dari pembelajaran berbasis konten menuju pembelajaran berbasis kompetensi (5) dari pembelajaran yang menekankan jawaban tunggal menuju pembelajaran dengan jawaban yang kebenarannya multidimensi.

Proses pembelajaran yang diselenggarakan secara interaktif, menyenangkan, menantang, inspiratif, memotivasi peserta didik untuk berpartisipasi aktif ini menjadikan penalaran sangat penting bagi peserta didik untuk meningkatkan kreativitas, kemandirian, mengembangkan kemampuan memecahkan masalah dan berpikir kritis.

\section{Simpulan dan Saran}

Berdasarkan data hasil penelitian dan pembahasan dapat disimpulkan bahwa: (1) satuan pendidikan dasar telah mengimplementasikan pembelajaran pada kurikulum 2013 meskipun masih perlu ditingkatkan kualitasnya, pemahaman guru-guru dalam mengimplementasikan model pembelajaran yang diperkenalkan dalam kurikulum 2013 juga baik, pelaksanaan pembelajaran dilaksanakan dengan berpusat pada peserta didik, (2) Implementasi K13 berjalan dengan baik, meskipun pada awalnya guru harus menyesuaikan dengan perubahan pola mengajar dan perangkat pembelajaran, dengan adanya diklat dan pelatihan-pelatihan sangat membantu, (3) Model yang diperkenalkan pada kurikulum 2013 telah membantu dalam peningkatan kemampuan bernalar siswa, akan tetapi perlu ditingkatkan kualitas pembelajarannya, (4) pembelajaran harus berpusat pada siswa, guru sebagai fasilitator, pembelajaran harus memberikan kesempatan kepada siswa untuk mencari tahu penyelesaian sebuah persoalan atau berinteraksi dengan lingkungan sosialnya, (5) model pembelajaran yang mudah diimplementasikan, model yang memberikan kesempatan kepada siswa mengemukakan ide atau gagasan dan memfasilitasi siswa berikir kritis, model pembelajaran yang memberikan kesempatan kepada siswa untuk bernalar, aktif dalam pembelajaran menyampaikan ide dan argumentasi atau memberikan alasan-alasan.

Saran yang dapat diberikan Dari hasil penelitian di atas dapat digunakan sebagai dasar dalam pengembangan model pembelajaran baru yang dapat meningkatkan kemampuan penalaran siswa. Pengembangan model pembelajaran advance organizer berbasis pendekatan open ended.

\section{Daftar Rujukan}

Baig, S \& Halai, A. (2006). Learning Mathematical Rules With Reasoning. Eurasia Journal of Mathematics, Science and Technology Education, 2(2), 15-33.

Badan Pengembangan Sumber Daya Manusia Pendidikan dan Kebudayaan. (2013). Materi Pelatihan Guru Implementasi Kurikulum 2013 SD Kelas I. Jakarta: Kementerian Pendidikan dan Kebudayaan.

Badan Pengembangan Sumber Daya Manusia Pendidikan dan Kebudayaan. (2015). Materi Pelatihan Guru Implementasi Kurikulum 2013 SD Kelas VI. Jakarta: Kementerian Pendidikan dan Kebudayaan.

Brodie, K. (2010). Teaching Mathematical Reasoning in Secondary School Classrooms. London: Springer. 
Fisher, A. (2009). Berpikir Kritis Sebuah Pengantar. Jakarta: Erlangga.

Borg, W., R., Gall, M., D. 1983. Educational Research An Introduction Fourth Edition. New York: Longman.

Gall, M. D., Gall, J. P. \& Borg, W. (2007). Educational Research an Introduction. Eighth edition. New York: Pearson.

Kemendikbud. (2014). Peraturan menteri pendidikan dan kebudayaan nomor 103 tentang Pembelajaran Pada Pendidikan Dasar dan Menengah. Jakarta: Kementerian Pendidikan dan Kebudayaan.

Kemendikbud. (2016). Peraturan menteri pendidikan dan kebudayaan nomor 22 tentang Standar Proses Pendidikan Dasar dan Menengah. Jakarta: Kementerian Pendidikan dan Kebudayaan.

Kusumawardani, D. R. Wardono, \& Kartono. (2018). Pentingnya Penalaran Matematika dalam Meningkatkan Kemampuan Literasi Matematika. Prisma 1(2018), Proceding. Prisma 1,Seminar Nasional Matematika: Unnes.

Namira, Z. B., Kusumo, E., \& Prasetya, A. T. (2014). Keefektifan strategi metakognitif berbantu advance organizer untuk meningkatkan hasil belajar kimia siswa. Jurnal Inovasi Pendidikan Kimia. 8(1), 1271-1280.

Pamungkas, T., Alamsyah, \& Turmudi. (2016). Kemampuan Berpikir Kritis dan Kreatif serta Self-Esteem Matematis Siswa melalui Model Advance Organizer. Jurnal Pendidikan Matematika, 1(2), 119-128.

Parjayanti, A. D., \& Wardono. (2013). studi komparasi model pembelajaran antara inkuiri dan advance organizer untuk penalaran matematis. Jurnal Kreano, 4(1), 64-72.

Putra, F. G., dkk. (2018). The Implementation of Advance Organizer Model on Mathematical Communication Skills in terms of Learning Motivation. Tadris: Journal of Education and Teaching Training, 3(1), 41-46.

Rahayu, S., Widodo, A. W., \& Supartono. (2010). Pengembangan Model Pembelajaran Advance Organizer Untuk Meningkatkan Aktivitas Dan Hasil Belajar Siswa. Jurnal Inovasi Pendidikan Kimia, 4(1), 497505.

Schunk, D. H. (2012). Learning Theories an Educational Perspective. Boston: Pearson.

Setyosari, P. (2012). Metode Penelitian Pendidikan dan Pengembangan. Jakarta: Kencana Prenada Media Group.

Shabania, N., Mardiati, Y., Sofyan, A. (2015). Pengaruh Pembelajaran Model Advance Organizer Terhadap Hasil Belajar Biologi Siswa Pada Konsep Protista. Jurnal Edusains, 7(1), 70-76.

Shadiq, F. (2004). Penalaran, Pemecahan Masalah dan Komunikasi dalam pembelajaran matematika. Yogyakarta: Departemen Pendidikan Nasional Pusat Pengembangan Penataran guru (PPPG) Matematika.

Shimada, S. (2005). The Open Ended Approach: A New Proposal For Teaching Mathematics. Virginia: National Council of Teacher of Mathematics.

Sugiyono. (2011). Metode Penelitian Kombinasi (Mixed Methods). Bandung: Alfabeta.

Suharnan. (2005). Psikologi Kognitif. Surabaya: Srikandi.

Sukmadinata, N. S. (2012). Metode Penelitian Pendidikan. Bandung: Remaja Rosdakarya.

Suwandi, S., dkk (2016). Pedoman Tesis dan Disertasi Pascasarjana Kependidikan Fakultas Keguruan dan Ilmu Pendidikan. Surakarta: UNS Press 